\title{
Analysis on Training Path for Professional Talents Led under Construction of Strengthening the Province through Intellectual Property
}

\author{
Jing Huangfu \\ Zhejiang Business College, Hangzhou, 310053, China
}

Key words:Intellectual property; talent training; path; analysis

\begin{abstract}
Zhejiang province is an intellectual property province, and it is also a talent province; therefore, it is an important task to carry out study on intellectual property talent training countermeasure which meets development requirement of Zhejiang economic and social development in construction of strengthening Zhejiang province through intellectual property. On the basis of surveying and researching training experience of domestic and foreign intellectual property talents, this paper systematically analyzes status and problems existing in training of intellectual property talents in Zhejiang Province, and proposes the thoughts and measures to enhance talent training in a targeted way for the purpose of providing decision-making reference for training of intellectual property talents of Zhejiang Province.

This paper is a soft science research project of Zhejiang Provincial Science and Technology Department of 2013, "research on training path for intellectual property talents and evaluation system of Zhejiang province” (project No.: 2013C25127)
\end{abstract}

\section{Survey and analysis on status of intellectual property talent team of Zhejiang province}

In recent years, we have carried out survey and research on intellectual property talents serving for creation, utilization, protection, management and other links of intellectual property in Zhejiang province. Through survey and research, we have found that there is a great increase in the toal number of intellectual property talents, the talent structure gradually meets the demand, the talents' ability of utilizing intellectual property is slighly improved, and a talent team including administrative management and law enforcement of intellectual property, intellectual property management of enterprise and public institutions, intellectual property service industry and teaching research is basically formed.

1. The intellectual property administrative management and law enforcement teams are increasing.

The intellectual property administrative management and law enforcement teams are important part of Chinese intellectual property talent team, and they are the leading force which drive the development of intellectual property undertaking. With implementation of intellectual property strategy, the intellectual property administrative management institutions at different levels are continuously perfected, and the administrative management and law enforcement talent teams are continuously expanded. In Zhejiang province, three-level (provincial, municipal, county) management team has been basically formed in intellectual property administrative mangement system, with totally 158 people involved; as for some counties, even township or subdistrict is arranged with intellectual property talent team. There are toally 34 full-time patent administrative law enforcement personnel at provincial and municipal level, including 23 personnel with patent administrative law enforcement certificate issued by State Intellectual Property Office, and 23 personnel with administrative law enforcement certificate (patent) issued by provincial (minicipal) law department. The intellectual property administrative management and law enforcement teams are gradually increasing.

2. The enterprise intellectual property management teams are growing.

The enterprises are front line of competition of intellectual property; in particular, the intellectual property management talents of export-oriented and service-oriented enterprises keep growing and developing in practice of operation and right protection of intellectual property. For example, Geely 
Group introduced professional talents to handle the affair about purchasing intellectual property of Volvo and practiced its team. Some associations also practice a batch of personnel in settling dispute about intellectual property. By the end of 2012, 4 prefecture-level cities in Zhejiang province had carried out professional title accreditation work on intellectual property (patent) engineers of enterprise and public institutions, and it had been confirmed that there were 569 engineers with primary title and 757 engineers with intermediate title.

Table 1. Statistical table of number of intellectual property (patent) engineers in Zhejiang province

\begin{tabular}{|c|c|c|c|}
\hline Level & Region & Number & Total \\
\hline \multirow{3}{*}{$\begin{array}{c}\text { Patent assistant engineer } \\
\text { (primary) }\end{array}$} & Hangzhou & 145 & \multirow{2}{*}{569} \\
\cline { 2 - 3 } & Wenzhou & 180 & \multirow{2}{*}{} \\
\cline { 2 - 3 } & Huzhou & 153 & \\
\cline { 2 - 3 } & Jiaxing & 91 & \multirow{2}{*}{757} \\
\hline \multirow{2}{*}{$\begin{array}{c}\text { Patent engineer } \\
\text { (intermediate) }\end{array}$} & Hangzhou & 147 & \\
\cline { 2 - 3 } & Wenzhou & 300 & \\
\cline { 2 - 3 } & Huzhou & 214 & \\
\cline { 2 - 3 } & Jiaxing & 96 & \multirow{2}{*}{1326} \\
\hline Total & & \multicolumn{2}{|c|}{} \\
\hline
\end{tabular}

3. The intellectual property service industry teams tend to be professional.

With increasing refined division of labor in society, the division of labor in intellectual property service industry tends to be professional. The social demand for intellectual property talents in application for agency, right protection and arbitration, evaluation of intangible assets, analysis on patent information, and operation and strategic planning, and the talent teams tend to be professional; the practitioners must obtain corresponding practicing qualification and then can engage in service work. By the end of June 2013, there were totally 46 patent agency institutions in Zhejiang province, 14 branches of institutions of other provinces in Zhejiang province, 640 patent agents (352 agents with practicing qualification), and about 2,000 practitioners in agencies. Furthermore, there were 3 assessment firms which could provide assessment on intangible assets such as patents, trademarks, and copyright, including 1 firm of other provinces in Zhejiang province. Besides, the services, such as analysis on patent information, operation and strategic planning of intellectual property, are mainly provided by intellectual property service institutions with public benefit, such as provincial intellectual property service center, municipal or county research institute of scientific and technological information.

\section{Intellectual property talent team demand and problem analysis}

In terms of actual situation of Zhejiang province, there exist some problems such as small quantity, low quality, unreasonable structure and distribution, and growth environment to be improved in intellectual property teams.

\section{Small quantity of talents}

In terms of administrative management and law enforcement teams, the size of personnel force of provincial intellectual property office can't meet the demand of business development, and the size of personnel force in Zhejiang is slighly larger than that in Tibet, Hainan, and Shanxi and ranked at the 4th last place in China. The quantity of patent application in Zhejiang province is ranked at the 2nd place in place. Based on the fact that the number of patent administrative law enforcement cases in Zhejiang accounts for $5 \%$ of cases in China, the intellectual property (patent) management 
in Zhejiang province has been under overloaded working condition.

In terms of enterprises, there are 34,697 industrial enterprises above scale and 560,000 scientific and technical personnel in Zhejiang province, but there are only 1,326 intellectual property engineers at present. According to the international practice and experiences of some multinational corporations, the enterprises and scientific research institutions shall arrange intellectual property management personnel based on $1 \% \sim 4 \%$ of research \& development technicians. If Zhejiang province arranges the personnel based on 1\% 2\%, it needs 5,600-11,200 people; if the calculation is made based on the situation that the engineer title identification is carried out in 11 prefecture-level cities, the goal can be met through 5-10 years of training, thus the gap is great.

In terms of intermediary services, one agent in top agencies in western countries acts as an agent for only 6 patents in one year; however, the agents in Japan have large workload, and one agent acts as an agent for 50 patents in one year. In 2012, there were 33,265 applications for patents in Zhejiang province; according to Japanese agents' workload, 665 agents were needed in 2012, and there existed almost half gap. By comparison with other provinces or cities (table blow), by the end of 2012, Beijing and Shanghai had the most agents and basically had no gap; Jiangsu province had the biggest agent gap among 5 provinces (cities), and the situation in Zhejiang province was close to that in Guangdong province. Among 5 provinces (cities), Zhejiang province had the least quantity of practicing agents.

Table 2. List of demand and gap of agents of 5 provinces (cities) in 2012 based on standard of annual per capita 50 inventions

\begin{tabular}{|c|c|c|c|c|c|}
\hline \multirow[t]{2}{*}{ Region } & \multirow[t]{2}{*}{$\begin{array}{l}\text { Number } \\
\text { of } \\
\text { agencies }\end{array}$} & \multirow[t]{2}{*}{$\begin{array}{l}\text { Number of } \\
\text { practicing } \\
\text { agents }\end{array}$} & \multirow[t]{2}{*}{$\begin{array}{l}\text { Application } \\
\text { quantity }\end{array}$} & \multicolumn{2}{|c|}{$\begin{array}{lll}\text { Counted based } & \text { on } \\
\text { annual per capita } & 50 \\
\text { inventions } & & \\
\end{array}$} \\
\hline & & & & Demand & Gap \\
\hline Beijing & 251 & 3254 & 50720 & 1014 & 0 \\
\hline Shanghai & 84 & 952 & 37139 & 743 & 0 \\
\hline Guangdong & 117 & 864 & 60448 & 1209 & 345 \\
\hline Jiangsu & 59 & 380 & 110091 & 2202 & 1821 \\
\hline Zhejiang & 46 & 352 & 33265 & 665 & 313 \\
\hline
\end{tabular}

In terms of education and research institutions, the talents are mainly distributed in 5 universities in which the intellectual property bachelor and master degree are set; because the curriculum provision and professional development are still under exploration stage, there are not more than 50 full-time talents who engage in intellectual property research and teaching. As the sources of talent supply, the universities have weak power both in providing basic talents of intellectual property research and in providing application-oriented talents engaging in teaching.

\section{Low talent quality}

The intellectual property interdisciplinary talents are very deficient. The so-called interdisciplinary talents refer to talents who know technology, law, management, and market. As for Zhejiang province, there are only 14 people listed into top 100 high-level talents and leading talents of State Intellectual Property Office; furthermore, those people don't play a role in negotiation and overseas right protection. Through qualification examination on 77 personnel sent to participate in overseas training by 4 batches (table below), the provincial intellectual property office finds that the talents who meet the features of interdisciplinary talents mainly come from enterprises, agencies, and law firms; however, those 3 kinds of talents only account for $38.9 \%$ of total trained talents at abroad. 
Table 3 Table of industrial distribution of overseas training personnel organized by provincial intellectual property office in 2009-2012

\begin{tabular}{|c|c|c|c|c|c|c|c|c|c|}
\hline \multirow[t]{2}{*}{$\begin{array}{c}\text { Indus } \\
\text { try }\end{array}$} & \multicolumn{2}{|c|}{$\begin{array}{c}\text { Universities } \\
\text { and } \\
\text { institutions }\end{array}$} & \multirow[t]{2}{*}{$\begin{array}{l}\text { Law } \\
\text { firms }\end{array}$} & \multicolumn{2}{|c|}{$\begin{array}{l}\text { Administration } \\
\text { of justice }\end{array}$} & \multicolumn{2}{|c|}{$\begin{array}{c}\text { Administrative } \\
\text { departments }\end{array}$} & \multirow[t]{2}{*}{$\begin{array}{l}\text { Enterpr } \\
\text { ises }\end{array}$} & \multirow[t]{2}{*}{ Agencies } \\
\hline & $\begin{array}{l}\text { Uni } \\
\text { vers } \\
\text { ities }\end{array}$ & $\begin{array}{c}\text { Instit } \\
\text { ution } \\
\mathrm{s}\end{array}$ & & $\begin{array}{c}\text { Procur } \\
\text { atorate } \\
\mathrm{s}\end{array}$ & $\begin{array}{c}\text { Cour } \\
\text { ts }\end{array}$ & Patent & $\begin{array}{c}\text { Other } \\
\text { s }\end{array}$ & & \\
\hline $\begin{array}{c}\text { Quan } \\
\text { tity }\end{array}$ & 20 & 6 & 26 & 3 & 9 & 6 & 3 & 2 & 2 \\
\hline $\begin{array}{c}\text { Prop } \\
\text { ortio } \\
n\end{array}$ & $26 \%$ & $7.8 \%$ & $33.7 \%$ & $3.9 \%$ & $\begin{array}{c}11.7 \\
\%\end{array}$ & $7.8 \%$ & $3.9 \%$ & $2.6 \%$ & $2.6 \%$ \\
\hline
\end{tabular}

In enterprises, there are only small quantity of practice-based intellectual property talents. According to questionnaire survey, there are about 18,000 (full-time or part-time) personnel engaging in intellectual property management work of enterprises in Zhejiang province; however, most of personnel engage in management in part-time way, and their main responsibilities are to contact with agencies and relevant administrative departments, know basic knowledge about intellectual property and handle business process via short-term training of local administrative departments, thus they are not intellectual property management talents of true sense.

\section{Unreasonable talent structure and regional distribution}

In terms of intellectual property administrative management and law enforcement team, people with law enforcement qualification and experience accounts for a low proportion (only 21.5\%) in the whole management team. The talents are mainly distributed in Hangzhou, Ningbo, and Wenzhou. In terms of enterprise intellectual property management, the current intellectual property (patent) engineers only account for $12 \%$ of total number of full-time (part-time) enterprise intellectual property management personnel (18,000 personnel) in Zhejiang province.

In terms of intellectual property service industry, the personnel with agent practicing qualification account for a low proportion (about 20\%), but the personnel without practicing experience account for a large proportion. Furthermore, the unreasonable age structure, specialty structure, and regional distribution in agent teams are more obvious.

Firstly, the age structure is unreasonable. Currently, among agencies in Zhejiang province, there are 120 practicing agents below 40 years old, accounting 34.4\% of total practicing agents; 180 agents above 55 years old, accounting for $51.6 \%$ of total agents, thus the agent team shows an aging trend. Secondly, the specialty structure is unreasonable. The agents in traditional chemical industry and machinery industry account for a large proportion, but the professional service talents in emerging field such as information industry, new energy, new materials, and bioengineering are deficient.

\section{Talents' growth environment to be improved}

(1) The policy support for training of intellectual property talents is deficient. The government departments above county level in Zhejiang province have special expenditure for intellectual property, but the policy support for training of intellectual property talents is deficient. Except that the provincial office formulates overseas training policy for high-end talents, most of policy-based expenditure at municipal and county level are subsidiary for patent application, and there is only little appropriation expenditure for talent training.

(2) The intellectual property academic education is detached from social demand. The intellectual property undergraduate program of universities in Zhejiang province are all set in law school; the teachers engaging in teaching commonly lack of intellectual property practice experience, and the students basically can't contact practice operation of intellectual property in studying process. Furthermore, after graduation, the students obtain Diploma of Arts; they can neither participate in agent examination, nor participate in intellectual property engineer evaluation, which makes many graduates have embarrassed employment plight and results in great run-off of reserve force. 


\section{Countermeasues and suggestions for training of intellectual property talents}

According to the construction requirement of strengthening Zhejiang province through intellectual property, the overall goal of intellectual property talent work of Zhejiang province in future 5 years is to take Deng Xiaoping's Theory, important thought of "Three Representatives", and scientific outlook on development as guidance, focus on economic and social development, and intellectual property career development of Zhejiang province, center on practice and application, innovate talent mechanism, deeply implement talent training plan, optimize policy environment, establish a work system good for talent growth and development, and promote the construction of different levels and classes of intellectual property talent teams.

\section{To establish and perfect intellectual property talent training mechanism}

(1) To perfect intellectual property talent training and development mechanism. It is required to fully exert the basic function of education in talent training and development, promote universities to establish intellectual property major, establish intellectual property second-level discipline, add master and doctor stations of intellectual property, support Wenzhou Institute of Intellectual Property to carry out professional training of intellectual property talents, enhance special training of intellectual property talents, take practice as orientation, enhance practice training, and depend on major special task, key research project, major engineering project, international communication and other platforms to train talents.

(2) To establish perfect talent evaluation and discovery mechanism. It is required to promote establishment of intellectual property talent professional technical title qualification system. According to the overall requirement of deepening the reform of title system, it is required to perfect the title system which meets features of professional intellectual property talents, research and establish a uniform technical title qualification and employment system for intellectual property engineers. On the basis of summarizing and perfecting intellectual property (patent) engineer professional technical title qualification work, it is required to explore and establish intellectual property advanced professional technical title system, further unify the technical title qualification and employment system for intellectual property engineers, and spare no efforts to train a great batch of patent management personnel with excellent quality and reasonable knowledge structure.

\section{To deeply implement intellectual property talent training plan}

(1) High-level talent leading plan. The intellectual property administrative departments, enterprises and public institutions, intellectual property intermediary service institutions, universities, and research institutions at different levels shall actively establish platform and create condition for training high-level intellectual property talents. Through organizing overseas special training and other ways, it is required to train and select a batch of high-level intellectual property talents which have intellectual property law and strategic research, intellectual property management and practice skills, and are familiar with international rules and international affairs of intellectual property.

(2) Intellectual property administrative management and law enforcement talent training plan. It is required to further enrich intellectual property administrative management talent teams at provincial, municipal, and county level, form a stable intellectual property management team with high quality, and perfect intellectual property administrative institutions at different levels; focus on improving social management and public service ability of intellectual property, and greatly enhance the knowledge training for administrative management cadres of intellectual property-related systems in Zhejiang province.

\section{To enhance macro-management and service, and optimize work environment}

(1) To improve and perfect intellectual property talent work management mechanism. It is required to establish scientific decision-making mechanism, coordinate mechanism and supervise the implementation of mechanism, form a talent work and operation mechanism in which there is combination of centralization and decentralization between provincial, municipal, county departments and enterprises, universities, and intermediaries, linkage between higher and lower levels, coordinated efficiency, and overall advance, and also form an overall resulting force of intellectual property talent work. The provincial intellectual property management department shall 
play the leading role, assign special department to take charge of intellectual property talent work, establish and perfect work goal, timely research and deploy talent work, get hold of direction, integrate the power, and solve the problems.

(2) To form a stable government input mechanism for intellectual property talent training and development. With reference to talent training experience and practice of Beijing city and Guangdong province, it is able to establish "special fund for intellectual property talent training" to enhance the force on intellectual property talent training of Zhejiang province. In annual work expenditure, the provincial intellectual property office sets special fund for intellectual property (patent) talent training project, and this fund is mainly used to hold training class for 100 high-level intellectual property talents and training class for 1,000 professional intellectual property talents. The intellectual property office above municipal level shall list talent training expenditure into annual budget, arrange special expenditure to carry out training for 10,000 intellectual property talents, and also encourage qualified prefecture-level cities to formulate talent training plan which conforms to actual situation of local region.

\section{References}

[1] Zhejiang Provincial Intellectual Property Office: Status of Intellectual Property Protection and Development in Zhejiang Province (2009-2012)

[2] State Intellectual Property Office: "the 12th Five-Year Plan” for Intellectual Property Talents (2011-2015, November 23, 2010)

[3] Complied by Tao Xinliang: Research on China's Intellectual Property Talent Training, Shanghai University Press (version 2006). 